\title{
PEMBERDAYAAN MASYARAKAT MELALUI PELATIHAN KARYA CIPTA RAMAH LINGKUNGAN UNTUK MENINGKATKAN JIWA WIRAUSAHA
}

\section{Fitri Herdianti}

IKIP Siliwangi Bandung

Fitriherdianti97@gmail.com

\begin{abstract}
ABSTRAK
Kita ketahui mungkin Pemerintah sudah mempunyai banyak program untuk masyarakat agar mereka semua menjadi masyarakat yang berdaya tetapi tidak banyak program juga yang tidak terealisasikan dengan baik atau bahkan belum bisa mengimplikasikan program secara menyeluruh. Disamping itu belum ada kesiapan dari pengambil kebijakan untuk merencanakan program yang benarbenar memberdayakan masyarakat secara menyeluruh. Berbicara mengenai wirausaha mereka yang menjadi wirausaha adalah orang-orang yang mengenal potensi dan dapat melihat peluang serta belajar mengembangkannya untuk menangkap peluang serta mengorganisasi usaha dalam mewujudkan cita-citanya. Penelitian ini bertujuan untuk 1) Mendekskripsikan perencanaan pemberdayaan masyarakat melalui pelatihan karya cipta ramah lingkungan untuk meningkatkan jiwa wirausaha. 2) untuk mendekskripikan hasil pemberdayaan masyarakat melalui pelatihan karya cipta ramah lingkungan untuk meningkatkan jiwa wirausaha. teori yang digunakan dalam penelitian ini yaitu pengertian pemberdayaan, pengertian pelatiha, dan pengertian wirausaha. Metode yang digunakan pada penelitian ini adalah deskriptif dan menggunakan pendekatan kualitatif. Teknik pengumpulan data yang digunakan yaitu wawancara dan observasi. Penelitian ini berlokasi di Saung Kreatif Ulul Azmi, Cipageran yang menjadi responden pada penelitian ini adalah ketua, dan 6 orang peserta yang mengikuti program ini. Berdasarkan hasil penelitian bahwa program ini sudah berjalan dengan baik sesuai dengan visi misi yang telah dibuat. Kesimpulan dari penelitian ini dari perencanaan mereka sudah cukup baik karena terlebih dahulu sudah melakukan identifikasi sehingga sesuai dengan kebutuhan masyarakat perlukan. Dan hasil programnyapun sudah baik sesuai dengan visi misi mereka, apalagi dengan keberanian peserta yang sudah percaya diri membuka stand bazzar ketika dalam suatu event.
\end{abstract}

Kata kunci: kewirausahaan, pemberdayaan, pelatihan

\section{PENDAHULUAN}

Negara Indonesia merupakan salah satu Negara dengan berbagai macam keindahan lingkungan yang tidak bisa kita remehkan. Selain itu juga karena Negara kita masih banyaknya lingkungan yang alami di beberapa daerah, Negara kita ini bahkan menjadi salah satu paru-paru dunia. Namun, sangat disayangkan kondisi lingkungan di Indonesia saat ini sudah banyak mengalami kerusakan serta pergantian iklim yang menjadi permasalahan global, terutama dengan banyaknya kerusakan lingkungan di seluruh penjuru dunia dan juga pergantian iklim yang menjadi masalah global. 
Ternyata beraneka ragam sekali kerusakan lingkungan yang sudah terjadi di Indonesia seperti banjir, pencemaran lingkungan, kerusakan hutan dan masih banyak lagi. Hal tersebut bisa terjadi karena kemungkinan 2 faktor yaitu terjadi karena faktor alam dan ulah manusia itu sendiri. Menurut data Badan Nasional Penanggulangan Bencana (BNPB) Data sementara, tercatat 2.341 kejadian bencana selama tahun 2017. Rincian kejadian bencana tersebut terdiri dari banjir (787), puting beliung (716), tanah longsor (614), kebakaran hutan dan lahan (96), banjir dan tanah longsor (76), kekeringan (19), gempabumi (20), gelombang pasang dan abrasi (11), dan letusan gunungapi (2). Sekitar 99 persen adalah bencana hidrometeorologi, yaitu bencana yang dipengaruhi oleh cuaca dan aliran permukaan (Nugroho, 2017). Dari data tersebut dapat disimpulkan bahwa ternyata kerusakan lingkungan yang terjadi di Indonesia kian memburuk. Selain mengalami kerusakan Indonesiapun akan mengalami kerugian yang cukup besar bahkan bisa mencapai triliunan. Dari banyaknya kerugian yang dialami akibat kerusakan lingkungan di sekeliling kita membuat banyak orang berfikir untuk bisa mempertahankan hidupnya, salah satunya dengan cara mengubah musibah menjadi peluang bagi kita sendiri dengan cara berfikir kreatif mengubah hal yang dirasa kurang bermanfaat menjadi hal yang bernilai jual.

Seperti banjir salah satu factor utamanya disebabkan ulah manusia itu sendiri yaitu membuang sampah sembarangan. Seperti yang terjadi di Kota Cimahi, banyaknya tumpukan sampah tersebut sehingga memicu kerusakan lingkungan terjadi. Menurut Kepala UPT Persampahan Dinas Lingkungan Hidup (DLH) Kota Cimahi, jika mengacu pada tahun lalu, ucapnya kenaikan volume sampah bisa meningkat mencapai 10 hingga 15 persen (Kamaludin, 2018). Dari data tersebut peningkatan sampah di Kota Cimahi rupanya kian meningkat. Sebenarnya tidak semua sampah itu menjadi sampah, banyak yang bisa kita gunakan dari bahan-bahan sampah untuk kita olah menjadi sesuatu yang bermanfaat. Sampah-sampah tersebut bisa saja kita gunakan sebagai ladang untuk melakukan wirausaha dari bahan-bahan dasar sampah merupakan bahan yang ramah lingkungan seperti plastic, kertas, daun-daun kering dsb. Ramah lingkungan yang dimaksud disini yaitu mudah di cari karena biasa kita temukan dalam sehari-hari.

Selain itu bahan dasar sampah juga merupakan bahan yang ramah lingkungan karena biasa kita temukan di kehidupan sehari-hari. Mungkin Pemerintah sudah mempunyai banyak program untuk masyarakat agar mereka semua menjadi masyarakat yang berdaya tetapi tidak banyak program juga yang tidak terealisasikan dengan baik atau bahkan belum bisa mengimplikasikan program secara menyeluruh. Disamping itu belum ada kesiapan dari pengambil kebijakan untuk merencanakan program yang benar-benar memberdayakan masyarakat secara menyeluruh.

Berbicara mengenai wirausaha mereka yang menjadi wirausaha adalah orang-orang yang mengenal potensi dan dapat melihat peluang serta belajar mengembangkannya untuk menangkap peluang serta mengorganisasi usaha dalam mewujudkan cita-citanya. Kewirausahaan merupakan kemampuan kreatif dan inovatif, jeli melihat peluang dan selalu terbuka untuk setiap masukan dan perubahan yang positif yang mampu membawa bisnis terus bertumbuh serta memiliki nilai. Menurut Joko Widodo mengatakan, rata-rata 14 persen penduduk negara maju merupakan entrepreneur hampir di setiap negara maju, 
standardnya itu memiliki (penduduk) entrepreneur di atas 14 persen. Sementara di kita, angkanya masih 3,1 persen itu artinya perlu percepatan (Kuwado, 2018).

Mereka tidak sadar bahwa setiap harinya sampah yang mereka buang bisa menghasilkan sesuatu yang bermanfaat. Baik itu menambahkan life skill mereka atau bahkan meningkatkan pertumbuhan ekonomi mereka dengan berwirausaha dari bahan dasar sampah ini, secara tidak langsung dari sampah inilah masyarakat bisa menjadi berdaya. Dari permasalahan lingkungan yang terjadi sebenarnya masyarakat bisa diberikan ilmu baru seperti pelatihan-pelatihan khusus mengenai pemanfaatan sampah tersebut. Maka dari itu disini penulis melakukan penelitian yang berjudul " Pemberdayaan Masyarakat Melalui Pelatihan Karya Cipta Ramah Lingkungan untuk Meningkatkan Jiwa Wirausaha”.

\section{LANDASAN TEORI}

Pengertian Pemberdayaan

(Malik, 2012) pemberdayaan merupakan suatu proses yang disengaja dan berlangsung secara terus menerus yang dipusatkan di dalam kehidupan komunitas lokal, meliputi: saling menghormati, sikap refleksi kritis, adanya kepedulian dan partisipasi kelompok, yang melaluinya masyarakat uyang merasa kurang memiliki secara bersama sumbersumber yang berharga menjadi memperoleh akses yang lebih besar untuk mendapatkan dan mengontrol sumber-sumber tersebut.

Dapat disimpulkan bahwa pemberdayaan masyarakat merupakan cara yang digunakan untuk meningkatkan harga diri manusia terutama mereka yang berada dalam lilitan kemiskinan dan ketidakberdayaan. Oleh karena itu agar seseorang berdaya, langkah pertama yang harus dilakukan adalah memberikan akses dimana potensi masyarakat tersebut bisa menjadi berkembang. Dengan masyarakat yang berdaya dibidang ekonomi, otomatis menambah pendapatan daerah.

Pengertian Pelatihan

Menurut Edwin B. Flippo (Mustofa Kamil, 2010 : 3) mengemukakan bahwa "training is the act of increasing the knowledge and skill of an employee for doing a particular job" (pelatihan adalah tindakan meningkatkan pengetahuan dan keterampilan seorang pegawai untuk melaksanakan pekerjaan tertentu).

Maka dapat disimpulkan bahwa pelatihan merupakan upaya untuk meningkatkan kualitas sumber daya manusia. Pelatihan membantu manusia dalam memahami suatu pengetahuan praktis dan penerapannya, guna meningkatkan keterampilan, kecakapan, dan sikap yang diperlukan oleh organisasi dalam usaha mencapai tujuan.

Pengertian kewirausahaan

Dalam pendapat (Saragih, 2017) kewirausahaan merupakan suatu proses dinamis untuk menciptakan nilai tambah atas barang dan jasa serta kemakmuran.

Jadi, wirausaha dapat diartikan sebagai manusia yang mampu melakukan kegiatan / pekerjaan untuk mencapai suatu maksud yang dalam bidang perdagangan perusahaan dengan maksud mencari untung, bahkan mampu membantu terutama dalam menciptakan lapangan kerja bagi orang lain 


\section{METODE PENELITIAN}

Metode penelitian yang digunakan dalam penelitian ini adalah atas dasar dari sejumlah masalah yang tertuang diidentifikasi masalah serta disesuaikan dengan tujuan penelitian, maka metode penelitian ini menggunakan metode deskriptif kualitatif Metode ini menjelaskan tentang prosedur dan teknik yang dilakukan untuk melakukan suatu penelitian.

Menurut (Sugiyono, 2014) metode deskriptif adalah suatu metode yang digunakan untuk menggambarkan atau menganalisis suatu hasil penelitian tetapi tidak digunakan untuk membuat kesimpulan yang lebih luas.

Pendekatan kualitatif yaitu penelitian dengan menggunakan metode ilmiah untuk mengungkapkan suatu fenomena dengan cara mendekskripsikan data dan fakta melalui kata-kata secara menyeluruh terhadap subjek penelitian (Mulyana D. , 2010).

Penelitian ini berlokasi di Saung Kreatif Ulul Azmi , Cipageran dan teknik pengumpulan data yang digunakan pada penelitian ini yaitu melalui wawancara dengan ketua Saung Kreatif Ulul Azmi dan enam orang peserta program pelatihan sebagai sampel.

\section{HASIL DAN PEMBAHASAN}

\section{Hasil}

Dari hasil penelitian yang di lapangan berikut ini peneliti akan memaparkan hasil yang ada dilapangan sesuai dengan pertanyaan penelitian yaitu 1. Bagaimana perencanaan pemberdayaan masyarakat melaui pelatihan karya cipta ramah lingkungan untuk meningkatkan jiwa wirausaha. 2. Bagaimana hasil pemberdayaan masyarakat melalui pelatihan karya cipta ramah lingkungan untuk meningkatkan jiwa wirausaha

Yang pertama yaitu pembahasana mengenai bagaimana perencanaan pemberdayaan masyarakat melaui pelatihan karya cipta ramah lingkungan untuk meningkatkan jiwa wirausaha menurut hasil di lapangan dan wawancara dengan para narasumber diperoleh hasil bahwa

Sebagaimana hasil wawancara dengan IM yaitu selaku ketua Saung Kreatif Ulul Azmi, “.... Yang pertama kami melakukan identifikasi masyarakat, kompetensi yang ada di masyarakat yang bisa di gali kemudian bisa kami kembangkan. Sasaran dari program itu sendiri yaitu ibu-ibu PKK Cipageran. Kendala yang dialami ketika program berjalan yaitu warga belajar setiap pertemuan semakin berkurang dalam mengikuti pelatihan ini. Program yang dilakukan Saung Kreatif ini sudah sesuai dengan kebutuhan masyarakat karena berdasarkan identifikasi terlebih dahulu. Untuk pendanaan mereka hanya menggunakan peralatan bekas yang ada dirumah-rumah yang ramah lingkungan sesuai dengan nama pelatihan ini. Tujuan dari program ini yaitu agar masyarakat sekitar dapat mandiri yaitu bisa melakukan wirausaha dengan memanfaatkan barang yang tadinya tidak ada manfaat menjadi sesuatu yang bermanfaat. Keuggulan dari program ini yaitu memandirikan masyarakat, memberikan keterampilan, memanfaatkan sesuatu yang tadinya tidak manfaat menjadi sesuatu yang bermanfaat. 
Pembahasan mengenai hasil pemberdayaan masyarakat melalui pelatihan karya cipta ramah lingkungan untuk meningkatkan jiwa wirausaha dengan salah satu responden dari peserta EK pemberdayaan sebagai berikut :".... Tujuan dari program ini sudah sesuai dengan yang diharapkan. Hambatan dalam pelaksanaan program ini yaitu tidak adanya pendanaan hanya memanfaatkan yang ada. Dengan adanya program ini tentunya ada perubahan yang dirasakan masyarakat setelalah melakukan proram karena mereka sudah bisa mandiri, dan dapat membantu pertumbuhan ekonomi mereka. Dngan program yang diberikan kepada masyarakat tentunya berhasil karena ibu-ibu PKK sudah pernah melakukan seperti bazzar ketika ada event. Luaran yang dihasilkan sampai saat ini yaitu mereka sudah bisa mengikuti bazzar ketika ada event tertentu. Untuk saat ini mereka belum ada yang melakukan wirausaha mandiri tapi sebagian dari mereka sudah ada yang mulai tertatanam untuk melakukan wirausaha.

\section{Pembahasan}

Hasil dari dari penelitian yang dilakukan mengenai bagaimana perencanaan pemberdayaan masyarakat melalui pelatihan karya cipta ramah lingkungan untuk meningkatkan jiwa wirausaha sudah baik mulai dari langkah awal membuat program pelatihan, sampai pelaksanaan pelatihan. Sebelum melakukan program pelatihanpun semua berdasar kan identifikasi terlebih dahulu sehingga pada saat program ini berjalan sesuai dengan kebutuhan masyarakat dan juga sesuai dengan visi, misi pada Saung Kreatif. Di saung kreatif ulul azmi yang memberdayakan dari ibu ibu pkk yang memiliki semangat pembangunan serta kreatif sengaja memanfaatkan barang barang bekas yang diolah menjadi sesuatu yang bisa dimanfaatkan lagi. Dan hal tersebut dilakukan secara terus menerus, selagi masih ada bahan yang tersedia. Kemudian dalam proses pembuatan karya cipta yang ramah lingkungan tersebut membentuk masyarakat yang kreatif, mandiri dan tentunya sebuah produk yang senantiasa di pasarkan dan di promosikan dalam sebuah acara dengan cara membuka stand saung kreatif ulul azmi.

Hal ini sesuai dalam pendapat (Saragih, 2017) kewirausahaan merupakan suatu proses dinamis untuk menciptakan nilai tambah atas barang dan jasa serta kemakmuran

Dan juga sesuai dengan pendapat (Malik, 2012) mengungkapkan pemberdayaan merupakan suatu proses yang disengaja dan berlangsung secara terus menerus yang dipusatkan di dalam kehidupan komunitas lokal, meliputi: saling menghormati, sikap refleksi kritis, adanya kepedulian dan partisipasi kelompok, yang melaluinya masyarakat uyang merasa kurang memiliki secara bersama sumber-sumber yang berharga menjadi memperoleh akses yang lebih besar untuk mendapatkan dan mengontrol sumber-sumber tersebut

Pembahasan mengenai bagaimana Bagaimana hasil pemberdayaan masyarakat melalui pelatihan karya cipta ramah lingkungan untuk meningkatkan jiwa wirausaha sudah cukup baik karena banyak beberapa dari warga belajar sudah ada yang bisa megikuti bazzar,paling tidak mulai muncul tertanam percaya diri pada warga belajar hingga nantinya bisa ditingkatkan untuk melakukan wirausaha mandiri dan program yang diadakan ini selaras dengan pendapat 
Menurut (Ansori, 2014), seorang entrepreneur atau wirausahawan dalam menjalankan sesuatu selalu dengan pertimbangan yang matang dan tidak asal-asalan, itulah yang membedakan entrepreneur sejati dengan entrepreneur asal jadi. Sehingga dapat diketahui ciri-ciri seorang entrepreneur sejati ialah ia memiliki jiwa wirausaha. Adapun ciri-cirinya adalah sebagai berikut:

1) Percaya diri

Kepercayaan diri merupakan suatu paduan sikap dan keyakinan seseorang dalam menghadapi tugas atau pekerjaan. Dalam praktik, sikap dan kepercayaan ini merupakan sikap dan keyakinan untuk memulai, melakukan dan menyelesaikan suatu tugas atau pekerjaan yang dihadapi. Oleh sebab itu kepercayaan diri memiliki nilai keyakinan, optimis, individualitas, dan ketidaktergantungan. Seseorang yang memiliki kepercayaan diri cenderung memiliki keyakinan akan kemampuannya untuk mencapai keberhasilan.

2) Berorientasi pada tugas dan hasil

Seseorang yang selalu mengutamakan tugas dan hasil, adalah orang yang selalu mengutamakan nilai-nilai motif berprestasi, berorientasi pada laba, ketekunan dan ketabahan, tekad kerja keras, mempunyai dorongan kuat, energik, dan berinisiatif.Berinisiatif artinya selalu ingin mencari dan memulai.Untuk memulai diperlukan niat dan tekad yang kuat, serta karsa yang besar. Sekali sukses atau berprestasi, makasukses berikutnya akan menyusul, sehingga usahanya semakin maju dan semakin berkembang.

\section{KESIMPULAN}

Memberdayakan merupakan upaya yang berkelanjutan sesuai dengan dinamika perubahan sosial budaya ataupun ekonomi yang berlangsung secara cepat dalam era global. Mungkin banyak program pemerintah untuk memperbaiki permasalahanpermasalahan sosial yang terjadi di Indonesia. Salah satunya program yang berada di Saung Kreatif Ulul Azmi ini dari perencanaanya mereka sudah cukup baik karena terlebih dahulu sudah melakukan identifikasi sehingga sesuai dengan kebutuhan masyarakat perlukan. Dan dari hasil programnyapun sudah baik sesuai dengan visi misi mereka, apalagi dengan keberanian peserta yang sudah percaya diri membuka stand bazzar ketika dalam suatu event.

\section{DAFTAR PUSTAKA}

Ansori. (2014). Model Pengembangan Kewirausahaan Santri Melalui Pondok Pesantren Berbasis Budaya Agribisnis Tanaman Palawija. Didaktik, 7.

Saragih, R. (2017). Membangun Usaha Kreatif, Inovatif dan Bermanfaat melalui Penerapan Kewirausahaan Sosial. Jurnal Kewirausahaan, 27.

Kamaludin, H. (2018, 05 27). tribunjabar.id. Retrieved from http://jabar.tribunnews.com/20218/05/27/volume-sampah-di-kota-cimahimeningkat-selama-bilan-ramadhan 
Kuwado, F. J. (2018, 04 05). kompas.com. Retrieved from https://nasional.kompas.com/read/2018/04/05/17261391/jumlah-entrepreneurdi-indonesia-jauh-di-bawah-negara-maju-ini-kata-jokowi

Mulyana, D. (2010). Metodelogi Penelitian Kualitatif "Paradigma baru ilmu komunikasi dan ilmu sosial lainnya". Bandung: PT Remaja Rosdakarya.

Nugroho, S. P. $\quad(2017,12$ 29). 1 www.bnpb.go.id. Retrieved from https://www.bnpb.go.id/2341-kejadian-bencana-377-tewas-dan-35-juta-jiwamengungsi-dan-menderita-akibat-bencana-tahun-2017

Kamil, M. (2010). Model Pendidikan dan Pelatihan . Bandung: Alfabeta.

Saragih, R. (2017). Membangun Usaha Kreatif, Inovatif dan Bermanfaat melalui Penerapan Kewirausahaan Sosial. Jurnal Kewirausahaan, 27.

Malik, H. A. (2012). Pemikiran Agama Untuk Pemberdayaan. Jurnal Dinas, 193. 